\title{
Jurist-Diction
}

Volume 4 No. 6 November 2021

\section{Karakteristik Penguasaan Pasar Perusahaan Transportasi Online}

\author{
Ranesya Maharani Alkemsky \\ ranesya.maharani.alkemsky-2017@fh.unair.ac.id \\ Universitas Airlangga
}

How to cite:

Ranesya Maharani Alkemsky

'Karakteristik Penguasaan

Pasar Perusahaan Transportasi

Online' (2021) Vol. 4 No. 6

Jurist-Diction

Histori artikel:

Submit 15 Oktober 2021;

Diterima 29 Oktober 2021;

Diterbitkan 5 November 2021.

DOI:

10.20473/jd.v4i6.31853

p-ISSN: 2721-8392

e-ISSN: $2655-8297$

\section{Abstract}

Market mastery is an activity that is often carried out by the business with the aim to dominate the market which can furthermore provide great benefits to the business actor. In order to gain power in the market, business actors often take actions that are contrary to the law, so as to potentially cause anti-competition in the market concerned. In the field of online transportation, mainly in Indonesia there are two large companies, namely PT Gojek and PT Grab. Both companies are said to be the holders of dominant positions, due to their status as large companies. Its existence in this dominant position is easy to have the potential to dominate the market, and if it happens then both companies can deter other business actors who are in the same market share.

Keywords: Market Mastery; Business Actors; Anti-Competition; Market Concerned; Dominant Position.

\begin{abstract}
Abstrak
Penguasaan pasar merupakan kegiatan yang kerap dilakukan oleh pelaku usaha dengan tujuan untuk menguasai pasar yang selanjutnya dinilai dapat memberikan keuntungan besar kepada pelaku usaha tersebut. Demi mendapatkan kekuasaan pada pasar tersebut, pelaku usaha tak jarang melakukan tindakan yang bertentangan dengan hukum, sehingga berpotensi mengakibatkan adanya anti persaingan pada pasar bersangkutan. Dalam bidang transportasi online utamanya di Indonesia terdapat dua perusahaan besar yakni PT Gojek dan PT Grab. Kedua perusahaan tersebut dikatakan sebagai pemegang posisi dominan, karena statusnya yang adalah perusahaan besar. Keberadaannya pada posisi dominan ini mudah untuk memliki potensi menguasai pasar, dan apabila hal itu terjadi maka kedua perusahaan tersebut dapat menghalangi pelaku usaha lainnya yang berada pada pangsa pasar yang sama.

Kata Kunci: Penguasaan Pasar; Pelaku Usaha; Anti Persaingan; Pasar Bersangkutan; Posisi Dominan.
\end{abstract}

Copyright (C) 2021 Ranesya Maharani Alkemsky

\section{Pendahuluan}

Seiring dengan adanya perkembangan zaman dan semakin majunya teknologi secara tidak langsung memberikan dorongan kepada pelaku usaha untuk berlombalomba memberi inovasi yang terdepan dalam mengembangkan usahanya. Hal tersebut mengakibatkan persaingan antar pelaku usaha yang terjadi saat ini semakin ketat. 
Selain persaingan yang semakin ketat, pelaku usaha harus berlomba-lomba untuk menjadi yang terdepan dalam memberi inovasinya. Dalam melakukan kegiatan usahanya pelaku usaha tetap diminta untuk bersaing secara sehat sebagaimana telah ditetapkan dalam Undang-Undang Nomor 5 Tahun 1999 tentang Larangan Praktek Monopoli dan Persaingan Usaha Tidak Sehat (selanjutnya disebut UU 5/1999)

Dalam UU 5/1999 telah dinyatakan secara eksplisit bahwa persaingan dalam dunia usaha diperbolehkan, asal tidak melanggar hal-hal yang dilarang dalam undang-undang tersebut. Meruntut isi dari UU 5/1999 pasal per pasal mengenai macam kegiatan yang dilarang dalam persaingan usaha salah satunya adalah penguasaan pasar.

Penguasaan pasar sendiri memiliki makna yang dapat diartikan pelaku usaha yang melakukan penguasaan di pasar dengan tujuan untuk memperoleh keuntungan dan pelaku usaha kadang kala melakukannya dengan Tindakan-tindakan yang bertentangan dengan hukum. ${ }^{1}$ Pasal 19 UU 5/1999 menyatakan bahwa penguasaan dapat dilakukan dengan cara menolak dan atau menghalangi pelaku usaha tertentu untuk melakukan kegiatan usaha yang sama pada pasar bersangkutan; atau menghalangi konsumen atau pelanggan pelaku usaha pesaingnya untuk tidak melakukan hubungan usaha dengan pelaku usaha pesaingnya itu; atau membatasi peredaran dan atau penjualan barang dan atau jasa pada pasar bersangkutan; atau melakukan praktek diskriminasi terhadap pelaku usaha tertentu.

Melihat perkembangan usaha dalam bidang transportasi, khususnya penyedia jasa transportasi online yang belakangan sangat diminati oleh khalayak masyarakat, terlebih pada beberapa tahun belakangan ini transportasi online mulai menjadi bagian dari kebutuhan masyarakat dalam menjalani kehidupan seharihari. Indonesia sendiri baru mengenal layanan transportasi online sekitar tahun 2014 hingga 2015 dan digunakan hingga sekarang untuk memenuhi kebutuhan masyarakatnya. ${ }^{2}$ Transportasi online tidak hanya digunakan untuk mengantarkan

\footnotetext{
${ }^{1}$ Andi Fahmi Lubis, [et.al.], Hukum Persaingan Usaha Buku Teks (KPPU 2017).[165].

${ }^{2}$ Aulia Masna, 'Layanan Uber Resmi Hadir di Jakarta Hari Ini' (Daily Social 2014) <https:// dailysocial.id/post/layanan-uber-resmi-hadir-di-jakarta-hari-ini> accessed 29 September 2020.
} 
ataupun menjemput penumpang saja, tetapi seiring perkembangan zaman fasilitas yang diberikan pun turut meluas, seperti fitur transportasi online tersebut dapat digunakan untuk mengirimkan barang, membeli makanan, dan lain sebagainya.

Berawal dari munculnya transportasi online di Indonesia yang awalnya belum terlalu banyak diminati oleh masyarakat karena dirasa membingungkan dimana harus menggunakan ponsel untuk memakai jasa transportasi online tersebut, terlebih bagi kalangan usia lanjut. Namun seiring berjalannya waktu penggunaan ponsel semakin diminati dari seluruh kalangan yang akhirnya timbul pengembangan jasa transportasi online yang awalnya hanya satu perusahaan yang menaungi yaitu Uber, yang menjadi jasa transportasi online pertama di Indonesia, kemudian disusul oleh Gojek, lalu disusul oleh Grab, dan lain sebagainya. Pada tahun 2020 saat ini sudah terdapat beberapa perusahaan penyedia jasa transportasi online yang berdiri di Indonesia, sehingga masyarakat dapat memilih jasa transportasi online yang dikehendakinya, tentunya dengan berbagai macam opsi yang sesuai dengan keinginannya. ${ }^{3}$

Sebagai perusahaan yang menyediakan jasa transportasi tentu memerlukan jasa mitra untuk bergabung sebagai pengemudi dari kendaraan yang akan dipergunakan, namun dalam perekrutan para mitranya kerap terjadi perlakuan yang tidak sesuai salah satunya adalah perilaku diskriminasi. Dalam hal ini PT Solusi Transportasi Indonesia (selanjutnya disebut PT Grab) sebagai perusahaan penyedia aplikasi jasa transportasi online dan PT Teknologi Pengangkutan Indonesia (selanjutnya disebut PT TPI) selaku penyedia layanan transportasi yang akan digunakan untuk mengangkut penumpang dalam perekrutan para mitra yang akan bergabung tersebut terdapat syarat dan ketentuan, salah satunya mitra diharapkan untuk bergabung menjadi bagian dari PT TPI dengan harapan untuk mempermudah pendistribusian mitra-mitra tersebut dalam hal penyewaan kendaraan dengan biaya yang lebih murah. Melihat dari perspektif lain bahwa dengan bergabungnya mitra dengan PT TPI selain para mitra jadi lebih terbantu dengan fasilitas yang ditawarkan, terdapat

\footnotetext{
${ }^{3}$ R1, 'Daftar Penyedia Jasa Transportasi Online di Indonesia' (Reaktor.co.id, 2014) $<$ https:// reaktor.co.id/daftar-penyedia-jasa-transportasi-online-di-indonesia/> accessed 28 September 2020.
} 
pula keuntungan-keuntungan lain berupa order prioritas. Adanya keuntungankeuntungan tersebut hanya didapatkan oleh para mitra yang bergabung dengan PT TPI saja sedangkan dengan mitra non-TPI (sebutan untuk mitra yang tidak bergabung dengan PT Transportasi Pengangkutan Indonesia) tidak mendapatkan fasilitas sebagaimana yang didapatkan oleh mitra yang bergabung dengan PT TPI.

Dari keseluruhan layanan yang dimiliki oleh PT Grab sebagai penyedia aplikasi jasa transportasi online dan PT TPI sebagai penyedia moda transportasi, perusahaan yang juga berstatus sebagai pelaku usaha diminta untuk menaati peraturan-peraturan yang berlaku di negaranya, seperti Indonesia para pelaku usaha diminta untuk tunduk pada Undang-undang yang berlaku terkhusus pada UU tentang Larangan Praktek Monopoli dan Persaingan Usaha Tidak Sehat. ${ }^{4}$ Dalam undangundang tersebut terdapat sejumlah larangan yang harus dipatuhi oleh pelaku usaha dengan tujuan agar terjaganya keseimbangan antara kepentingan pelaku usaha dan kepentingan umum.

Salah satu bentuk larangan yang diberikan oleh Undang-undang Nomor 5 Tahun 1999 tentang Larangan Praktek Monopoli dan Persaingan Usaha Tidak Sehat kepada pelaku usaha adalah melakukan praktek diskriminasi terhadap pelaku usaha tertentu. Melihat adanya kemungkinan dampak yang ditimbulkan dari praktek diskriminasi dalam kasus ini adalah adanya pelaku usaha pesaing yang tersingkir dari pasar bersangkutan dan timbulnya praktek monopoli. Bentuk perlakuan praktek diskriminasi yang dilakukan oleh pelaku usaha terhadap pelaku usaha tertentu salah satunya adalah penunjukkan langsung dalam suatu pekerjaan, tanpa justifikasi legal, sosial, ekonomi, teknis dan alasan lainnya yang dapat diterima. ${ }^{5}$

Berdasarkan kasus posisi dari isi putusan KPPU NOMOR 13/KPPU-I/2019 yang menyatakan bahwa PT Grab dan PT TPI melakukan kerja sama dalam perihal

\footnotetext{
${ }^{4}$ Sidharta, 'catatan seputar hukum persaingan usaha' (Business Law Binus, 2013) $<$ https:// business-law.binus.ac.id/2013/01/20/catatan-seputar-hukum-persaingan-usaha/> accssed 28 September 2020.

${ }^{5}$ Peraturan Komisi Pengawas Persaingan Usaha Nomor 3 Tahun 2011 Tentang Pedoman Pasal 19 Huruf D (Praktek Diskriminasi) Undang- Undang Nomor 5 Tahun 1999 Tentang Larangan Praktek Monopoli dan Persaingan Usaha Tidak Sehat
} 
melakukan kegiatan secara bersama-sama, dalam hal ini adalah kesepakatan untuk melakukan penentuan perlakuan yang berbeda terhadap mitra individu atau mitra yang tidak bergabung dengan PT TPI yang dapat mengakibatkan pelaku usaha pesaing yang tersingkir dari pasar bersangkutan hingga terjadinya praktek monopoli. ${ }^{6}$

\section{Metode Penelitian}

Tipe penelitian yang akan digunakan dalam penulisan ini adalah:

1. Tipe penelitian doktrinal (yuridis normatif), yaitu penelitian yang dilakukan dengan cara menelaah teori-teori, konsep-konsep, asas-asas hukum serta peraturan perundang-undangan yang berkaitan dengan penelitian ini. ${ }^{7}$

2. Tipe penelitian kepustakaan, yaitu penelitian yang dilakukan menggunakan pendekatan ini menggunakan literatur-literatur, peraturan perundang-undangan, dan dokumen-dokumen lainnya yang berkaitan dengan materi dari penelitian ini

\section{Pendekatan (Approach)}

Pendekatan penelitian yang akan digunakan dalam penulisan ini antara lain:

\section{Pendekatan Perundang-undangan (Statute Approach)}

Dengan pendekatan ini penulis meneliti perundang-undangan yang berlaku dan berkaitan dengan materi penelitian yang sedang dilakukan. Dalam hal ini penulis akan mencari ratio legis dan dasar ontologis lahirnya Undang-undang Nomor 5 Tahun 1999 tentang Larangan Praktek Monopoli dan Persaingan Usaha Tidak Sehat yang kemudian akan disimpulkan mengenai ada tidaknya keselarasan antara undang-undang tersebut dengan materi penelitian yang akan ditulis oleh penulis. ${ }^{8}$

2. Pendekatan Konseptual (Conceptual Approach)

\footnotetext{
${ }^{6}$ Putusan Komisi Pengawas Persaingan Usaha Nomor 13/KPPU-I/2019

${ }^{7}$ Vijay M Gawas, 'Doctrinal Legal Research Method A Guiding Principle In Reforming The Law And Legal System Towards The Research Development' (2017) 3 International Journal of Law.

${ }^{8}$ Peter Mahmud Marzuki, Penelitian Hukum (Prenada Media 2005).[133-134].
} [129]. 
2448 Ranesya Maharani: Karakteristik Penguasaan Pasar...

Penulis menggunakan pendekatan ini dengan mempelajari pandangan-pandangan dan doktrin-doktrin didalam ilmu hukum yang kemudian akan digunakan untuk melahirkan pengertian-pengertian hukum, konsep-konsep hukum, dan asas-asas hukum yang relevan dengan materi penelitian dan nantinya dapat digunakan untuk memecahkan isu dari materi penelitian tersebut. ${ }^{9}$

3. Pendekatan Kasus (Case Approach)

Penulis menggunakan pendekatan ini guna mempelajari penerapan norma yang terkandung dalam suatu kasus yang telah menjadi putusan, terkhusus pada Putusan KPPU NOMOR 13/KPPU-I/2019. ${ }^{10}$

\section{Bahan Hukum (Legal Sources)}

Sumber bahan hukum yang akan digunakan dalam penyusunan penulisan ini ada 2 (dua), yaitu:

1. Bahan Hukum Primer, yang meliputi peraturan perundang-undangan seperti:

a. Undang-undang Nomor 5 Tahun 1999 tentang Larangan Praktek Monopoli dan Persaingan Usaha Tidak Sehat;

b. Peraturan Komisi Pengawas Persaingan Usaha Nomor 3 Tahun 2011 Tentang Pedoman Pasal 19 Huruf D (Praktek Diskriminasi) Undang- Undang Nomor 5 Tahun 1999 Tentang Larangan Praktek Monopoli dan Persaingan Usaha Tidak Sehat.

2. Bahan Hukum Sekunder, yaitu bahan hukum yang bersumber dari bahan kepustakaan berupa buku, jurnal maupun artikel yang terdapat di internet, dan karya ilmiah ataupun bahan bacaan lainnya yang berkaitan dengan materi penelitian. Bahan bacaan buku yang digunakan oleh penulis salah satunya adalah Buku Ajar Hukum Persaingan Usaha yang diterbitkan oleh KPPU (Komisi Pengawas Persaingan Usaha). Bahan bacaan buku ini diperlukan oleh penulis dalam penulisan penelitian ini karena adanya keterkaitan materi penelitian dengan muatan materi yang terdapat di dalam buku ini, sehingga

\footnotetext{
${ }^{9}$ ibid. [135-136].
}

${ }^{10}$ ibid. [158]. 
penulis dapat memahami konsep diskriminasi yang menjadi topik utama dalam penulisan ini.

\section{Penguasaan Pasar dalam Hukum Persaingan Usaha}

Dalam hukum persaingan usaha tak lepas dari adanya kegiatan penguasaan pasar. Penguasaan pasar merupakan sebuah upaya atau tindakan yang dilakukan oleh satu atau lebih perusahaan yang memiliki tujuan untuk mempertahankan posisinya pada pasar bersangkutan. ${ }^{11}$

Pasar bersangkutan menurut pasal 1 angka 10 UU 5/1999 merupakan pasar yang berkaitan dengan jangkauan atau daerah pemasaran tertentu oleh pelaku usaha atas barang dan atau jasa yang sama atau sejenis atau substitusi dari barang dan atau jasa tersebut. Dengan begitu pasar bersangkutan dapat dikatakan sebagai sebuah konsep yang dilakukan guna mendefinisikan tentang ukuran pasar akan suatu produk. ${ }^{12}$

Penguasaan pasar juga tak lepas kaitannya dengan rumusan pasal $17 \mathrm{UU}$ 5/1999, yaitu tentang monopoli. Penguasaan pasar memiliki kaitan dengan monopoli sebagaimana perbuatan yang dilakukan dalam penguasaan pasar dilakukan secara jelas melanggar hukum dan merugikan pesaing dalam pasar bersangkutan. ${ }^{13}$

Kegiatan penguasaan pasar oleh para pelaku usaha umumnya digunakan untuk meningkatkan atau mempertahankan status dari perusahaannya tersebut untuk menempati posisi dominan. Posisi dominan tidak pula lepas kaitannya dengan penguasaan pasar. Menurut United Nation Model on Law Competition, penguasaan pasar adalah: "Dominant position of market power" refers to a situation where enterprise, either by itself or acting together with a few enterprises, is in a position to control the relevant market for a particular good or service or group or goods or services" yang dapat disimpulkan bahwa penguasaan pasar adalah kondisi pelaku

${ }^{11}$ Peraturan Komisi Pengawas Persaingan Usaha Nomor 3 Tahun 2011 Tentang Pedoman Pasal 19 Huruf D (Praktek Diskriminasi) Undang- Undang Nomor 5 Tahun 1999 Tentang Larangan Praktek Monopoli dan Persaingan Usaha Tidak Sehat.

${ }^{12}$ ibid.

${ }^{13}$ ibid. 
usaha secara sendiri maupun bersama dengan pelaku usaha lain mempunyai posisi untuk mengontrol suatu pasar bersangkutan. ${ }^{14}$ Dalam arti penguasaan pasar dapat dilakukan oleh pelaku usaha pemegang posisi dominan.

Dengan menempati posisi dominan tersebut pelaku usaha akan merasa mudah untuk menguasai pasar yang berada di pasar bersangkutan. Serta dengan adanya posisi dominan yang diperoleh, pelaku usaha dapat melakukan pengendalian terhadap harga-harga pada pasar bersangkutan. ${ }^{15}$

Selain itu penguasaan pasar dapat dilakukan oleh pelaku usaha yang memiliki market power atau kekuasaan atas pasar, yaitu pelaku usaha yang dapat menguasai pasar sehingga mampu menentukan harga suatu barang pada pasar bersangkutan. Umumnya kedudukan market power dapat dimiliki oleh pelaku usaha atau suatu kelompok pelaku usaha yang menguasai 50\% (lima puluh persen) atau lebih atau dua atau tiga pelaku usaha atau kelompok pelaku usaha yang menguasai 75\% (tujuh puluh lima persen) atau lebih. ${ }^{16}$

Adanya perbuatan penguasaan pasar tersebut juga menimbulkan beberapa akibat terhadap persaingan usaha yang sehat. Menurut Prof. Dr. Budi L. Kagramanto, S.H., M.H., M.M. Persaingan usaha dapat dikatakan sehat apabila telah memenuhi prinsip-prinsip seperti:

1. Terdapat produk substitusi;

2. Jumlah penjual dan pembeli seimbang;

3. Tidak terdapat hambatan masuk;

4. Penjual dan pembeli memiliki informasi produk yang berkenaan dengan harga dan kualitas produk;

5. Tidak ada diskriminasi;

6. Adanya penerapan prinsip keadilan;

7. Jenis produk inovatif;

8. Efisien.

Penguasaan pasar pada dasarnya tidak dilarang oleh UU 5/1999, tetapi dilarang apabila kegiatan penguasaan pasar tersebut menimbulkan dampak pada

\footnotetext{
${ }^{14}$ UN, 'Model on Law Competition, New York and Geneva' (2004).[3].

${ }^{15}$ Budi L. Kagramanto, Mengenal Hukum Persaingan Usaha (Laros 2012).[189].

16 ibid.
} 
persaingan usaha hingga persaingan usaha menjadi tidak sehat. ${ }^{17}$ Sebagaimana UU 5/1999 mengatur tentang wujud penguasaan pasar yang dilarang dapat berbentuk penjualan barang dan/atau jasa dengan cara:

a. Jual rugi (predatory pricing) dengan maksud untuk mematikan pesaingnya;

b. Melalui praktek penetapan biaya produksi (price fixing) yang dilakukan secara curang dan biaya lainnya yang menjadi komponen harga barang;

c. Perang harga atau persaingan harga (price war). ${ }^{18}$

Akibat dari perlakuan pelaku usaha yang melakukan penguasaan pasar antara lain dapat menimbulkan potensi pelaku usaha pesaing yang tersingkir dari suatu pasar bersangkutan. Bagi pelaku usaha kecil, perannya dapat tereduksi di dalam pasar bersangkutan tersebut. Dapat juga menimbulkan adanya pelaku usaha atau sekelompok pelaku usaha yang dapat bertindak secara semena-mena. Berpotensinya terjadi hambatan untuk masuk atau mengembangkan suatu pasar pada pasar bersangkutan tersebut. Potensi akan berkurangnya persaingan usaha secara sehat pada pasar bersangkutan tersebut. Serta pilihan konsumen yang dapat tereduksi di suatu pasar bersangkutan. ${ }^{19}$

Pengaturan tentang penguasaan pasar diatur dalam pasal 19 UU 5/1999 yang dinyatakan sebagai berikut: ${ }^{20}$

Pasal 19

Pelaku usaha dilarang melakukan satu atau beberapa kegiatan, baik sendiri maupun Bersama pelaku usaha lain, yang dapat mengakibatkan terjadinya praktek monopoli dan atau persaingan usaha tidak sehat berupa:

a. Menolak dan atau menghalangi pelaku usaha tertentu untuk melakukan kegiatan usaha yang sama pada pasar bersangkutan; atau

b. Menghalangi konsumen atau pelanggan pelaku usaha pesaingnya untuk tidak melakukan hubungan usaha dengan pelaku usaha pesaingnya itu; atau

\footnotetext{
${ }^{17}$ Andi Fahmi Lubis [et.,al.], Op.Cit.[138].

${ }^{18}$ ibid. [139].

${ }^{19}$ Komisi Pengawas Persaingan Usaha, DRAFT Pedoman Pelaksanaan Ketentuan Pasal 19 Undang-Undang No. 5 Tahun 1999 tentang Larangan Praktek Monopoli dan Persaingan Usaha Tidak Sehat.[23]

${ }^{20}$ Pasal 19 Undang-Undang No. 5 Tahun 1999 tentang Larangan Praktek Monopoli dan Persaingan Usaha Tidak Sehat
} 
c. Membatasi peredaran dan/atau penjualan barang dan/atau jasa pada pasar bersangkutan; atau

d. Melakukan praktek diskriminasi terhadap pelaku usaha tertentu

Terdapat unsur-unsur secara umum dari pasal 19 UU 5/1999 yang terdiri $\operatorname{atas}^{21}$

a. Pelaku usaha

Pelaku usaha dalam pasal 1 angka 5 dinyatakan sebagai setiap orang atau badan usaha, berbentuk badan hukum atau bukan badan hukum, yang didirikan dan berkedudukan atau melakukan kegiatan dalam wilayah hukum negara Republik Indonesia, baik sendiri maupun secara Bersama-sama melalui perjanjian, menyelenggarakan berbagai kegiatan usaha dalam bidang ekonomi.

b. Pelaku usaha lain

Dinyatakan dalam penjelasan pasal 17 ayat (2) huruf b, pelaku usaha lain adalah pelaku usaha yang mempunyai kemampuan bersaing yang signifikan dalam pasar bersangkutan

c. Praktek monopoli

Menurut pasal 1 angka 2 UU 5/1999, praktek monopoli merupakan pemusatan kekuatan ekonomi oleh satu atau lebih pelaku usaha yang mengakibatkan dikuasainya produksi dan/atau pemasaran atas barang dan/atau jasa tertentu sehingga menimbulkan persaingan usaha tidak sehat dan dapat merugikan kepentingan umum

d. Persaingan usaha tidak sehat

Pada pasal 1 angka 6 UU 5/1999, persaingan usaha tidak sehat adalah persaingan antar pelaku usaha dalam menjalankan kegiatan produksi dan/atau pemasaran barang dan/atau jasa yang dilakukan dengan cara tidak jujur atau melawan hukum atau menghambat persaingan usaha

Pada pasal 19 UU 5/1999 terdapat unsur atas "melakukan satu atau beberapa kegiatan". Terkait unsur tersebut terdapat penjabaran lebih lanjut yang terdapat pada pasal 19 huruf a, yaitu: ${ }^{22}$

a. Unsur menolak Menolak adalah Ketika pelaku usaha tidak bersedia untuk melakukan kegiatan usaha dengan pelaku usaha lain

b. Unsur menghalangi

Menghalangi adalah Ketika pelaku usaha melakukan kegiatan yang menciptakan hambatan bagi pelaku usaha lain

c. Unsur pelaku usaha tertentu

Pelaku usaha tertentu adalah pelaku usaha yang dirugikan oleh kegiatan

${ }^{21}$ Komisi Pengawas Persaingan Usaha, DRAFT Pedoman Pelaksanaan Ketentuan Pasal 19 UU 5/1999.Loc.Cit.

22 ibid. 
sebagaimana disebutkan dalam Pasal 19 huruf a dan d UU No. 5/1999.

d. Unsur kegiatan usaha yang sama

Kegiatan usaha yang sama adalah kegiatan usaha yang sejenis dengan yang dilakukan oleh pelaku usaha.

e. Unsur pasar bersangkutan

Berdasarkan Pasal 1 angka 10 UU No. 5/1999, pasar bersangkutan adalah pasar yang berkaitan dengan jangkauan atau daerah pemasaran tertentu oleh pelaku usaha atas barang dan/atau jasa yang sama atau sejenis atau substitusi dari barang dan jasa tersebut. Sejalan dengan pengertian di atas dan dari sudut pandang ekonomi, ada dua dimensi pokok yang harus dipertimbangkan untuk menentukan pengertian pasar bersangkutan, yaitu produk (barang atau jasa yang dimaksud) dan wilayah geografis.

Selanjutnya unsur yang terdapat pada pasal 19 huruf $b$ antara lain; ${ }^{23}$

a. Unsur konsumen

Menurut Pasal 1 angka 15 UU No. 5/1999, konsumen adalah setiap pemakai dan/atau pengguna barang dan/atau jasa untuk kepentingan diri sendiri maupun untuk kepentingan pihak lain.

b. Unsur pelanggan

Pelanggan adalah pemakai atau pengguna dari barang dan/atau jasa untuk kepentingan sendiri maupun kepentingan pihak lain yang menggunakan secara berkesinambungan, teratur, terus menerus baik melalui perjanjian tertulis maupun tidak tertulis.

c. Unsur pelaku usaha pesaing

Pelaku usaha pesaing adalah pelaku usaha yang berada dalam pasar bersangkutan yang sama.

d. Unsur hubungan usaha

Hubungan usaha adalah kegiatan ekonomi antar pelaku usaha dalam bentuk berbagai transaksi dan/atau kerja sama.

Kegiatan penguasaan pasar lainnya yang diatur dalam pasal 19 huruf c antara lain; ${ }^{24}$

a. Unsur membatasi peredaran

Membatasi peredaran adalah kegiatan yang dilakukan pelaku usaha dengan tujuan untuk mengendalikan distribusi atau wilayah peredaran barang dan/atau jasa.

b. Unsur barang

Berdasarkan Pasal 1 angka 16 UU No. 5/1999, barang adalah setiap benda baik berwujud maupun tidak berwujud, baik bergerak maupun tidak bergerak yang dapat diperdagangkan, dipakai, dipergunakan atau dimanfaatkan oleh konsumen 
atau pelaku usaha.

c. Unsur jasa

Berdasarkan Pasal 1 angka 17 UU No. 5/1999, jasa adalah setiap layanan yang berbentuk pekerjaan atau prestasi yang diperdagangkan dalam masyarakat untuk dimanfaatkan oleh konsumen atau pelaku usaha. Selain itu juga berkenaan dengan unsur yang terdapat pada Pasal 19 huruf d yang mencakup: ${ }^{25}$

a. Praktek diskriminasi

Praktek diskriminasi adalah termasuk di dalamnya menolak sama sekali melakukan hubungan usaha, menolak melakukan hubungan usaha, menolak syarat-syarat tertentu atau perbuatan lain, dimana pelaku usaha lain diperlakukan dengan cara tidak sama. Terjadi perbedaan perlakuan oleh pelaku usaha tertentu kepada pelaku usaha lainnya dalam suatu pasar bersangkutan.

Berkaitan dengan unsur-unsur dari pasal 19 UU 5/1999, dapat klasifikasikan beberapa bentuk penguasaan pasar yang dilarang oleh UU 5/1999 yang diantaranya adalah: ${ }^{26}$

1. Menolak pesaing (refusal to deal)

Menolak atau menghalang-halangi pelaku usaha tertentu (pesaing) dalam hal melakukan usaha yang sama pada pasar bersangkutan.

2. Menghalangi konsumen

Menghalang-halangi pihak konsumen dari pelaku usaha lain (pesaing) untuk tidak melakukan atau meneruskan hubungan usaha dengan pihak usaha pesaing tersebut. Yang dilakukan oleh pelaku usaha ialah dengan mengadakan perjanjian antara distributor dari pelaku usaha tersebut yang memasarkan produknya dengan pihak grosir, pengecer, ritel, atau toko yang menjual produknya tersebut kepada masyarakat. Dimana pelaku ataupun ritel dapat memasarkan produknya namun tidak boleh menjual produk-produk lain. Apabila para grosir, pengecer, maupun ritel ini menjual barang lain maka akan diberhentikan pengiriman barang oleh distributor dan ini jelas merugikan. Dengan perjanjian inilah kemudian bagi para pelaku usaha lain akan mengalami kesulitan di dalam memasarkan produknya.

3. Pembatasan peredaran produk

Dengan cara membatasi peredaran dan/atau penjualan barang dan/atau jasa pada pasar yang bersangkutan.

4. Diskriminasi terhadap pelaku usaha tertentu yang merupakan pesaingnya

5. Melakukan jual rugi (predatory pricing)

Pemasokan produk dengan cara jual rugi yaitu dengan menetapkan harga yang sangat rendah dengan maksud untuk menyingkirkan atau mematikan usaha pesaingnya agar tidak mampu lagi bersaing.

6. Penetapan biaya secara curang Melakukan kecurangan atau manipulasi dalam menetapkan biaya produksi dan

\footnotetext{
25 ibid.

${ }^{26}$ Andi Fahmi Lubis [et., al].Loc.Cit.
} 
biaya lainnya yang merupakan komponen harga produk sehingga harga lebih rendah daripada harga sebenarnya.

Dengan melihat pengertian dari penguasaan pasar yang berarti kegiatan untuk mendominasi suatu pasar bersangkutan dan termasuk dalam kegiatan monopolistik. Maka sebagian atau seluruh prinsip yang ditetapkan sebagai tolak ukur persaingan usaha yang sehat dilanggar oleh kegiatan penguasaan pasar.

\section{Perilaku Penguasaan Pasar yang Dilakukan oleh Perusahaan Transportasi Online}

Perusahaan transportasi sejatinya adalah perusahaan yang bergerak dalam bidang jasa yang menyediakan moda transportasi. Adanya perkembangan jaman yang semakin modern lahirlah perusahaan transportasi yang berbasis online dengan tujuan untuk memudahkan pengguna teknologi pada masa sekarang.

Perusahaan transportasi online sendiri merupakan perusahaan yang bergerak pada bidang transportasi yang berbasis aplikasi online. ${ }^{27}$ Keberadaan perusahaan transportasi online ini dikehendaki dapat menjadi solusi atas sistem transportasi di Indonesia yang dinilai masih belum mumpuni untuk akses kemudahan, kenyamanan, serta keamanannya. ${ }^{28}$ Pelopor dari perusahaan transportasi online salah satunya adalah Uber yang berasal dari Amerika Serikat dan didirikan pada tahun 2009. ${ }^{29}$ Yang kemudian berekspansi ke wilayah-wilayah dibagian Eropa, seperti Inggris, Polandia, Perancis, dan Italia. ${ }^{30}$ Indonesia sendiri termasuk salah satu negara yang awal dalam mendirikan perusahaan transportasi online, yakni Indonesia dengan Gojek pada tahun 2010. Pada waktu awal pendiriannya gojek hanya memiliki jumlah pengemudi sebanyak 40 orang, yang kemudian meluas menjadi lebih dari 400 pengemudi tersebar di seluruh Indonesia. Pada tahun 2012

\footnotetext{
${ }^{27}$ Endang Wahyusetyawati 'Dilema Pengaturan Transportasi Online', (2017), RechtsVinding https://rechtsvinding.bphn.go.id/jurnal_online/TRANSPORTASI\%20ONLINE_ENDANG.pdf accessed 26 Januari 2021.

${ }^{28} \mathrm{ibid}$.

${ }^{29}$ Kevin Anthony, 'Mengenal Penguasa Transportasi Online di Berbagai Negara' (CNBC Indonesia, 2018) <https:/www.cnbcindonesia.com/news/20180217144830-4-4629/mengenal-penguasa-transportasi-online-di-berbagai-negara> accessed 26 Januari 2021.

${ }^{30}$ ibid.
} 
didirikan perusahaan transportasi online Grab yang berasal dari Singapura, memiliki pasar yang meliputi negara-negara di Asia Tenggara, yakni Singapura, Malaysia, Filipina, Vietnam, Thailand, Myanmar, Kamboja, dan Indonesia. ${ }^{31}$ Dengan adanya perusahaan transportasi ini diharapkan mampu untuk memudahkan masyarakat dalam menggunakan moda transportasi umum di Indonesia.

Transportasi online di Indonesia diawali dengan kurangnya akses untuk menggunakan transportasi umum, yang dulunya hanya dapat dijangkau dengan akses secara konvensional. Karena dinilai kurang efisien seiring dengan perkembangan jaman, sehingga muncullah inovasi untuk mempermudah akses menggunakan transportasi umum dengan cara melalui aplikasi online. Perkembangan akses transportasi secara online terdapat peran serta dari pihak pengusaha start-up dalam bidang transportasi yang ingin membantu untuk menunjang mobilitas masyarakat yang tergolong tinggi.

Cara untuk memastikan bahwa perkembangan transportasi online di Indonesia ini tidak termasuk dalam perilaku anti persaingan, maka dilakukan penentuan terhadap pasar bersangkutan pada transportasi online. ${ }^{32}$ Pasar bersangkutan sendiri menurut pasal 1 angka 10 UU 5/1999 adalah pasar yang berkaitan dengan jangkauan atau daerah pemasaran tertentu oleh pelaku usaha atas barang dan/atau jasa yang sama atau sejenis atau substitusi dari barang dan/atau jasa tersebut. ${ }^{33}$ Dari isi pasal tersebut terdapat beberapa unsur, yaitu: unsur pasar, unsur jangkauan atau wilayah pemasaran, unsur pelaku usaha, dan unsur sejenis atau substitusi. ${ }^{34}$ Serta dari isi pasal tersebut juga menerangkan bahwa dalam pasar bersangkutan terdapat dua elemen, yakni elemen produk dan elemen wilayah geografis. ${ }^{35}$ Elemen produk dinyatakan melalui kalimat “... barang dan/atau jasa yang sama atau sejenis atau

\footnotetext{
${ }^{31}$ Loc.Cit.

${ }^{32}$ Andi Fahmi Lubis, [et., al].Op.Cit.[50].

${ }^{33}$ Undang-undang Nomor 5 Tahun 1999 tentang Larangan Praktek Monopoli dan Persaingan Usaha Tidak Sehat.Loc.Cit.

${ }^{34}$ Peraturan Komisi Pengawas Persaingan Usaha Nomor 3 Tahun 2009 Tentang Pedoman Penerapan Pasal 1 angka 10 tentang Pasar Bersangkutan Berdasarkan Undang-Undang Nomor 5 Tahun 1999 tentang Larangan Praktek Monopoli dan Persaingan Usaha Tidak Sehat.[5-6].

${ }^{35}$ Andi Fahmi Lubis,[et.al].Loc.Cit.
} 
substitusi dari barang dan/atau jasa tersebut" serta untuk elemen wilayah geografis dinyatakan melalui kalimat “ ... berkaitan dengan jangkauan atau daerah pemasaran tertentu".36

Pasar bersangkutan dalam persaingan usaha diperlukan untuk mengukur struktur pasar dan Batasan anti persaingan yang dilakukan oleh pelaku usaha. ${ }^{37}$ Pasar bersangkutan apabila dilihat dari elemen produk terdapat dua sisi, yaitu substitusi permintaan dari sisi konsumen dan substitusi dari sisi produsen. ${ }^{38}$ Pada substitusi permintaan dari sisi konsumen dilakukan dengan menginvestigasi sebuah produk atau jasa dan melihat substitusi yang paling mendekati dari produk atau jasa tersebut. ${ }^{39}$ Jika terdapat barang yang termasuk dalam substitusi terdekat, maka barang tersebut dapat dimasukkan kedalam batasan pasar bersangkutan jika substitusi yang dilakukan oleh konsumen tersebut berpotensi mencegah naiknya harga produk relevan yang sedang diinvestigasi menjadi diatas harga tingkat persaingan atau pada level kompetitif..$^{40}$

Cara untuk mengetahui apakah barang atau jasa tersebut termasuk pada pasar bersangkutan, dapat dilakukan dengan menguji menggunakan asumsi hypothetical monopolist test. ${ }^{41}$ Pengujian yang dilakukan dengan asumsi ini dilakukan dengan cara mengidentifikasi rangkaian kecil dari produk dan produsen, sebagaimana produsen adalah pemilik produk yang sedang diinvestigasi dan pengujian menggunakan hypothetical monopolist tersebut mengendalikan pasokan dari semua produk didalam rangkaian terkait yang dapat meningkatkan profit dengan cara menaikkan suatu harga diatas harga kompetitifnya, serta dapat menjadi dasar untuk pengaplikasian pada identifikasi pasar produk dan pasar geografis. ${ }^{42}$

Pasar produk dalam definisinya dijelaskan sebagai rangkaian produk-produk pesaing dari suatu produk tertentu dengan produk lain yang memiliki potensi untuk

\footnotetext{
${ }^{36}$ ibid.

${ }^{37}$ ibid.

${ }^{38}$ ibid.[50-51].

${ }^{39}$ ibid. [51].

${ }^{40}$ ibid.

${ }^{41}$ ibid.

${ }^{42}$ ibid.
} 
menjadi substitusi dari produk tersebut. ${ }^{43}$ Cara untuk mengetahui pasar produk dapat dilakukan identifikasi terhadap sisi permintaan yang kemudian dilanjutkan dengan sisi penawaran. ${ }^{44}$ Pada sisi permintaan, produk yang diinvestigasi berpotensi untuk memiliki produk substitusinya dan apabila produk tersebut sudah tidak lagi sesuai dengan permintaan maka dapatberakibat pindahnya konsumen yang semula menggunakan produk menjadi beralih menjadi menggunakan produk substitusi tersebut. ${ }^{45}$ Salah satu yang dapat beralihnya konsumen ke produk substitusi adalah perubahan harga dari produk, sedangkan pada sisi penawaran, produk dan produk yang berpotensi menjadi substitusi digunakan untuk menginvestigasi pelaku usaha yang dapat masuk ke pasar untuk memproduksi calon produk yang berpotensi untuk menjadi substitusi dari produk. ${ }^{46}$ Munculnya calon produk yang berpotensi untuk menjadi substitusi dari produk tersebut diakibatkan oleh salah satunya kenaikan harga daripada produk dan produk yang berpotensi untuk menjadi substitusi, maka pelaku usaha selaku produsen mengalihkan pengeluaran yang seharusnya digunakan untuk produk dan produk yang berpotensi untuk menjadi substitusi kepada calon produk yang berpotensi untuk menjadi substitusi. ${ }^{47}$

Pasar geografis mendasarkan pada suatu wilayah yang pelaku usahanya dapat melakukan pengaturan harga tanpa ada risiko dari pelaku usaha baru yang akan masuk atau dari konsumen yang menjadi beralih kepada pelaku usaha yang lain di luar suatu wilayah tersebut. ${ }^{48}$ Dalam penentuan Batasan wilayah pada pasar geografis dilakukan dengan cara mengidentifikasi harga dari suatu daerah secara substansial dapat mempengaruhi suatu daerah yang lainnya. ${ }^{49}$ Serta dapat dilihat pula dari sisi konsumen, yakni dengan cara apabila konsumen mendapatkan produk yang sama dengan cara yang mudah dari produsen di wilayah lain, maka wilayah lain tersebut

\footnotetext{
${ }^{43}$ Peraturan Komisi Pengawas Persaingan Usaha Nomor 3 Tahun 2009 Tentang Pedoman Penerapan Pasal 1 angka 10 tentang Pasar Bersangkutan Berdasarkan Undang-Undang Nomor 5 Tahun 1999 tentang Larangan Praktek Monopoli dan Persaingan Usaha Tidak Sehat.Op.cit.[10].

${ }^{44}$ ibid.

${ }^{45}$ ibid. [11].

${ }^{46} \mathrm{ibid}$.

${ }^{47}$ ibid.

48 ibid.

${ }^{49}$ ibid. [13].
} 
termasuk dalam pasar geografis. ${ }^{50}$ Pasar geografis dapat pula mencakup atas dua wilayah apabila terbukti bahwa harga dari suatu produk yang sedang dipermasalahkan tersebut bergerak secara bersamaan di kedua wilayah tetapi pergerakan produk tersebut tidak disebabkan oleh perubahan dari biaya produksinya. ${ }^{51}$

Berdasarkan uraian dari pasar produk dan pasar geografis yang merupakan bagian dari pasar bersangkutan, terdapat beberapa unsur dari pasar bersangkutan jika dilihat dari sisi pasar produk, yakni jenis, fungsi, dan harga. ${ }^{52}$ Dalam menentukan pasar bersangkutan berdasarkan dari unsur jenis yakni produk dalam suatu pasar tidak harus menjadi substitusi yang sempurna, karena terdapat keadaan tertentu yang tidak memungkinkan untuk mendapatkan produk dengan sifat substitusi yang sempurna, sehingga cukup didasarkan pada produk dengan substitusi yang terdekat. ${ }^{53}$ Pada unsur fungsi suatu produk tidak harus memiliki kualitas yang sama antara produk satu dengan produk yang lainnya, sepanjang produk tersebut fungsi yang sama dengan produk, maka produk tersebut dapat dikatakan sebagai substitusinya. ${ }^{54}$ dari unsur harga untuk menentukan pasar bersangkutan, harga produk harus mencerminkan harga pasar yang dapat bersaing secara sehat atau kompetitif. 55 Dalam pasar geografis pun terdapat beberapa faktor yang dapat mempengaruhi luas dan cakupan wilayahnya, yakni berkaitan dengan kebijakan perusahaan, biaya transportasi, lama waktu dari perjalanan, serta peraturanperaturan yang dapat membatasi lalu lintas antar kota atau wilayah. ${ }^{56}$

Mengenai hasil uraian tentang pasar bersangkutan yang terdiri dari pasar produk dan pasar geografis tersebut, dapat dilakukan analisis berkaitan dengan pasar bersangkutan pada perusahaan transportasi online di Indonesia. Bahwa dari sejumlah pelaku usaha di Indonesia yang bergerak dibidang transportasi online

\footnotetext{
${ }^{50}$ Andi Fahmi Lubis,[et.,al.], Op.Cit.[54].

${ }^{51}$ ibid.

${ }^{52}$ Peraturan Komisi Pengawas Persaingan Usaha Nomor 3 Tahun 2009 Tentang Pedoman Penerapan Pasal 1 angka 10 tentang Pasar Bersangkutan Berdasarkan Undang-Undang Nomor 5 Tahun 1999 tentang Larangan Praktek Monopoli dan Persaingan Usaha Tidak Sehat.Op.Cit.[14].

${ }^{53}$ ibid. [16].

${ }^{54}$ ibid.

${ }^{55}$ ibid. [14].

${ }^{56}$ ibid. [16-17].
} 
yakni PT Grab yang bergerak sejak tahun 2012 hingga saat ini dan juga PT Gojek yang berdiri sejak 2010 hingga saat ini, keduanya termasuk dalam perusahaan besar yang menguasai transportasi online di Indonesia. ${ }^{57}$ Cara untuk melakukan identifikasi terhadap perusahaan transportasi online di Indonesia tersebut akan dilakukan pertimbangan berdasarkan unsur dari pasar bersangkutan, yang pertama pada unsur karakteristik, dalam unsur ini produk substitusi tidak harus mencapai pada sifat substitusi yang sempurna, namun cukup dengan menjadi substitusi terdekat dari produk. ${ }^{58}$ Melihat unsur karakter tersebut apabila dikaitkan dengan perusahaan penyedia layanan transportasi online dapat dibuktikan dengan adanya dua perusahaan besar yakni PT Grab dan PT Gojek sebagai pelaku usaha penyedia jasa layanan transportasi online yang sama atau sejenis. Dengan demikian maka hubungan antara produk satu sama lain bersifat substitusi.

Selanjutnya melihat dari unsur fungsi yang mengutamakan keterkaitan suatu produk dengan produk substitusinya dan hal tersebut dapat dinyatakan dengan adanya pernyataan konsumen yang menyatakan bahwa suatu produk memiliki fungsi yang sama dengan produk yang berpotensi menjadi substitusi, maka produk dengan produk yang berpotensi menjadi substitusi dapat dikatakan sebagai substitusi antara satu sama lain. Melihat jasa yang ditawarkan oleh PT Grab dan PT Gojek adalah serupa, maka produk tersebut adalah substitusi antara satu sama lain, karena memiliki fungsi yang serupa yakni sama-sama merupakan perusahaan yang menyediakan layanan transportasi online. Bagian terakhir yakni melihat dari unsur harga, bahwa dalam unsur ini harga suatu produk harus mencerminkan harga pasar yang kompetitif yang didasarkan pada respon konsumen atas adanya perubahan harga pada suatu produk. ${ }^{59}$ Dalam unsur ini apabila akan ada peningkatan harga hanya dilakukan pada produk utama saja, dengan dalih peningkatan harga tersebut

\footnotetext{
${ }^{57}$ Roy Franedya, 'Siapa penguasa sejati pasar ojol RI, Grab atau Gojek?', CNBC Indonesia, 2019)<https://www.cnbcindonesia.com/tech/20191227065254-37-125903/siapa-penguasa-sejati-pasar-ojol-ri-grab-atau-gojek/2> accessed 13 Juni 2021.

${ }^{58}$ Peraturan Komisi Pengawas Persaingan Usaha Nomor 3 Tahun 2009 Tentang Pedoman Penerapan Pasal 1 angka 10 tentang Pasar Bersangkutan Berdasarkan Undang-Undang Nomor 5 Tahun 1999 tentang Larangan Praktek Monopoli dan Persaingan Usaha Tidak Sehat.Op.cit.[15].

${ }^{59}$ ibid.[14].
} 
tidak boleh menyebabkan inflasi serta jumlah peningkatan harganya harus sedikit namun signifikan agar konsumen bisa beralih ke produk substitusi terdekat dari produk utama. Dikaitkan dengan perusahaan penyedia layanan transportasi online, hal ini cukup relevan dengan jangkauan harga yang ditetapkan oleh PT Grab dengan PT Gojek, yang harga atau tarif diantara keduanya kurang lebih sama. PT Gojek lebih dahulu berdiri dan beroperasi di Indonesia dibandingkan dengan PT Grab, sehingga jika diumpamakan PT Gojek adalah produk utama sedangkan PT Grab sebagai substitusi terdekatnya. Pada saat PT Grab masuk di Indonesia, harga atau tarif layanan transportasi online yang disediakan oleh PT Gojek mengalami kenaikan, sehingga menyebabkan tarif yang digunakan oleh PT Gojek lebih tinggi dari PT Grab yang pada saat itu baru memasuki pasar Indonesia.

Sehubungan dengan unsur harga tersebut, terdapat kaitannya dengan market power atau kekuatan pasar. Market power sendiri adalah kemampuan pelaku usaha untuk menaikkan harga di atas tingkat persaingan tetapi masih memberikan keuntungan terhadap pelaku usaha tersebut. ${ }^{60}$ Umumnya kedudukan market power dapat dimiliki oleh pelaku usaha atau suatu kelompok pelaku usaha yang menguasai 50\% (lima puluh persen) atau lebih atau dua atau tiga pelaku usaha atau kelompok pelaku usaha yang menguasai 75\% (tujuh puluh lima persen) atau lebih. ${ }^{61}$ Adanya PT Grab dan PT Gojek yang saat ini menguasai pangsa pasar dari jasa transportasi online serta melihat karakteristik pasar dari perusahaan yang merupakan perusahaan besar dan produk atau jasanya yang homogen, maka dapat dikaitkan dengan struktur pasar oligopoli. Namun karena di Indonesia perusahaan yang menguasai jasa transportasi online hanya terdapat dua perusahaan, maka struktur pasarnya dapat dikatakan sebagai duopoli. ${ }^{62}$

Dalam duopoli terdapat beberapa model, yakni yang pertama adalah Model Cournot. Model Cournot ini jika terdapat 2 perusahaan maka masing-masing dari 2 perusahaan tersebut dapat menentukan kuantitas yang akan diproduksi dan kemudian dilanjutkan dengan menentukan harga yang sekiranya dapat diterima di

\footnotetext{
${ }^{60}$ Peraturan KPPU Nomor 6 Tahun 2010 tentang Pedoman Pasal 25 UU 5/1999.[22].

${ }^{61}$ Budi L. Kagramanto.Loc. Cit.

${ }^{62}$ Andi Fahmi Lubis, [et.,al.].Op.cit.[130].
} 
pasar. ${ }^{63}$ Model Cournot dapat diwujudkan apabila terjadi keseimbangan seperti:

a) pelaku usaha $\mathrm{A}$ bisa memperoleh keuntungan maksimal;

b) pelaku usaha B memperoleh keuntungan maksimal sama dengan pelaku usaha $A$;

c) seluruh hasil produksi pelaku usaha A dan B telah habis di pasar.

Keseimbangan yang diwujudkan oleh Model Cournot ini mendekati pasar keseimbangan dari persaingan sempurna. ${ }^{64}$ Dapat disimpulkan bahwa dalam Model Cournot para pelaku duopoli membuat pengaturan untuk membagi pasar menjadi 2 dan membaginya sama rata, serta setiap perusahaan yang terlibat menerima harga barang dan/atau jasa berdasarkan kuantitas atau ketersediaannya. Kedua perusahaan yang terlibat pun sebisa mungkin mempertahankan hubungan antara keduanya berkaitan dengan harga pasar. Tak dapat dipungkiri pula kedua perusahaan ini dapat berubah dalam hal ingin membuat perubahan dan penyesuaian terkait produksi barang dan/atau jasa terkait, dan hal ini semua dapat berakhir ketika keseimbangan terhadap pasar telah dicapai oleh masing-masing perusahaan. ${ }^{65}$

Model duopoli yang kedua adalah Model Bertrand. Pada Model Bertrand ini menekankan bahwa persaingan itu akan selalu didorong oleh harga dan dalam model ini pelaku usaha menentukan harga untuk mendapatkan keuntungan yang sebesar-besarnya melalui perhitungan yang telah disepakati bersama antara kedua pelaku usaha. Serta hal yang ingin diwujudkan dari model ini adalah antara pesaing satu sama lain untuk tetap mempertahankan tingkat harga jualnya. ${ }^{66}$ Model Bertrand identik dengan jika salah satu pelaku usaha menurunkan harga jual barang dan/atau jasanya, maka pelaku usaha yang satu lainnya akan ikut serta menurunkan harga jual barang dan/atau jasanya. Singkatnya kedua pelaku usaha tersebut akan menurunkan harga jualnya hingga mencapai titik harga barang dan/atau jasanya sama dengan biaya marginal. ${ }^{67}$ Disimpulkan dalam Model Bertrand ini perusahaan-perusahaan

${ }^{63}$ Lia Amalia, 'Perspektif Hukum Persaingan Usaha Terhadap Duopoli Pelaku Usaha Transportasi Online di Indonesia' (2020) 3 Widya Yuridika: Jurnal Hukum.[210].

${ }^{64}$ Adiwarman A. Karim, Ekonomi Mikro Islami (Raja Grafindo Persada 2007).[176].

${ }^{65}$ Lia Amalia.Loc. Cit.

${ }^{66} \mathrm{ibid}$.

${ }^{67}$ ibid. 
terkait tidak memiliki target untuk mencapai keuntungan maksimum atau minimum serta melihat dari sisi konsumen, konsumen tentu akan memilih menggunakan barang dan/atau jasa dari perusahaan yang menawarkan harga terbaik. ${ }^{68}$

Model duopoli berikutnya adalah Model Chamberlin. Pada model ini memiliki asumsi dasar yang sama seperti pada Model Cournot, akan tetapi model ini juga memberikan asumsi lebih lanjut terkait perusahaan duopoli yang mengakui adanya ketergantungan antara satu sama lain. Akibat yang ditimbulkan jika kedua perusahaan tersebut tidak memiliki kesepakatan atau kerja sama, kedua perusahaan tersebut berpotensi untuk menjual dengan harga yang sama, menjual dengan kuantitas yang sama, serta memaksimalkan keuntungan secara Bersama-sama. ${ }^{69}$ Model Chamberlin ini juga berasumsi bahwa menggunakan monopoli yakni dengan industri atau keuntungan Bersama menjadi maksimal dapat dicapai tanpa adanya kolusi. ${ }^{70}$

Model yang terakhir yakni Model Kurva Permintaan Patah atau (kinked demand curve), yakni adalah suatu terminologi variasi perkiraan yang tidak simetris tentang pandangan pada perubahan harga yang dimiliki oleh setiap perusahaan. Dengan harapan jika salah satu pelaku usaha menurunkan harganya maka pelaku usaha lainnya menurunkan harganya pula demi menjaga jumlah pelanggan atau pengguna dari barang dan/atau jasa yang dikeluarkan oleh pelaku usaha tersebut. ${ }^{71}$ Berikut ilustrasi dari kurva permintaan patah:

Gambar. Kurva Permintaan Patah

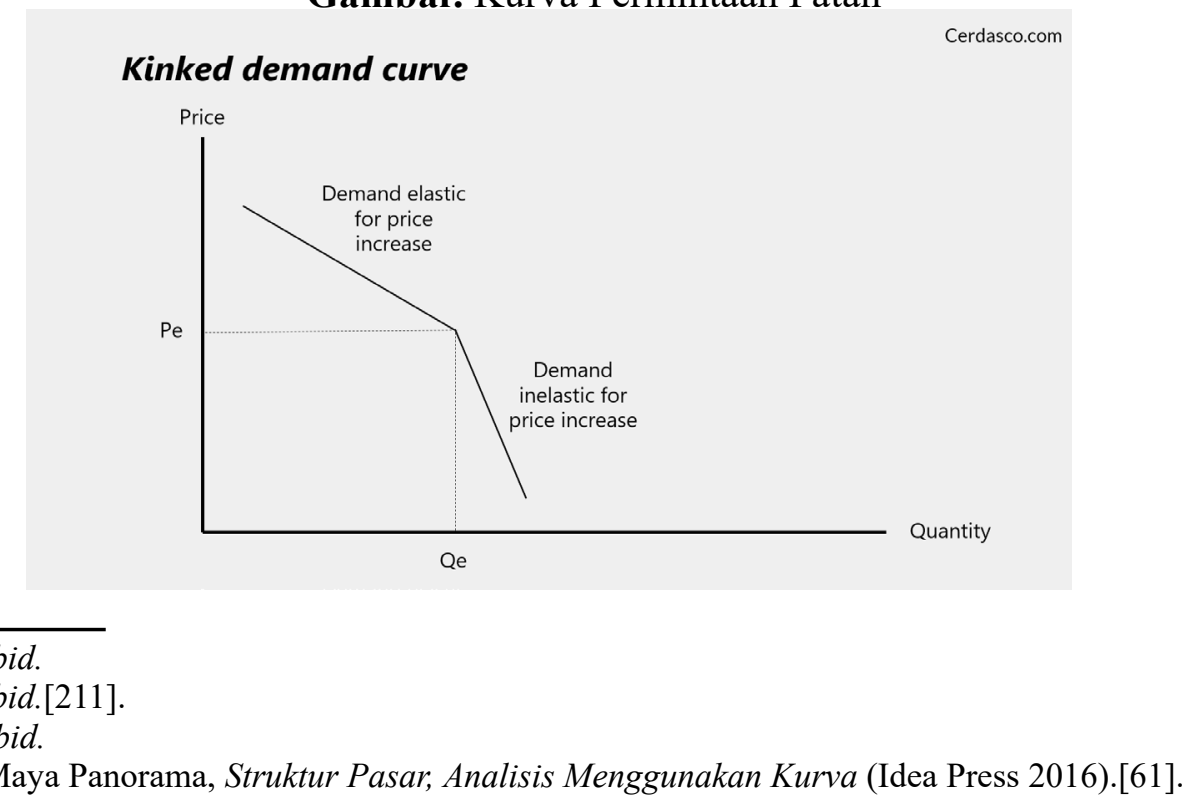


Sumber: Cerdasco.com https://cerdasco.com/model-kurva-permintaan-tertekuk/

Model-model duopoli diatas tersebut jika melihat dari pola yang dilakukan oleh PT Grab dan PT Gojek adalah mendekati dengan Model Chamberlin, karena dinilai dapat memicu adanya penguasaan pasar secara tidak sehat karena terjadi oligopoli dalam bentuk duopoli tersebut. Serta terdapat ketergantungan antara kedua perusahaan tersebut. ${ }^{72}$ Yang dilakukan oleh kedua perusahaan tersebut yakni PT Grab dan PT Gojek dapat dikatakan memenuhi unsur dari oligopoli, yakni terdapat beberapa penjual di pasar. Namun karena pada bidang transportasi online ini hanya terdapat dua pelaku usaha, maka dikategorikan sebagai oligopoli dalam bentuk duopoli. ${ }^{73}$ Unsur dari oligopoli yang kedua yakni adanya saling ketergantungan antara perusahaan terkait. Antara PT Grab dan PT Gojek dapat dikatakan saling ketergantungan karena adanya persaingan harga dan persaingan kuantitas, yang dapat dilihat pada saat PT Grab memberikan fasilitas promo berkala yang sebelumnya tidak terdapat pada PT Gojek, namun karena hal tersebut beberapa pengguna dari PT Gojek mulai berpindah ke pesaingnya, PT Gojek pun mengeluarkan promo berkala juga agar para pelanggan atau pengguna dari jasanya tersebut tidak jadi beralih kepada pesaingnya.

Posisi PT Grab dan PT Gojek sebagai perusahaan besar juga tak lepas dari potensi pemegang posisi dominan, karena kedua perusahaan tersebut merupakan pemegang pangsa pasar terbesar di Indonesia saat ini. ${ }^{74}$ Hal tersebut dapat dilihat dari jumlah pengguna dari jasa tersebut yakni pada PT Grab, telah terdapat di 224 kota di Indonesia serta pada PT Grab yang mencapai 203 kota di Indonesia. Serta jumlah pengguna dari Grab yang mencapai jumlah 18 juta dengan mitra sebanyak 2,8 juta dan Gojek dengan jumlah pengguna sebanyak 29,2 juta dengan jumlah mitra sebanyak 2 juta pada tahun $2020 .^{75}$

\footnotetext{
${ }^{72}$ Lia Amalia.Op.cit.[212].

${ }^{73}$ Andi Fahmi Lubis, [et., al.].Op.cit.[36].

${ }^{74}$ Lia Amalia.Op.Cit.[208].

${ }^{75}$ Ahmad Zaenudin, 'Kala Grab dan Gojek Goyah Akibat Corona' (Tirto.id, 2020) <https:// tirto.id/kala-grab-dan-gojek-goyah-akibat-corona-fKxg> diakses pada 21 Juni 2021.
} 
PT Grab yang memiliki potensi untuk melakukan duopoli karena merupakan perusahaan besar dan posisinya yang dominan mengabitkan hubungan dengan mitranya tidak seimbang. Hubungan yang dimiliki oleh PT Grab dan mitranya dapat dikatakan sebagai hubungan yang vertikal, karena sehubungan dengan posisi PT Grab sebagai perekrut mitra. Mitra pada PT Grab ada pada naungan PT TPI yakni sebagai perusahaan afiliasi dari PT Grab. ${ }^{76}$ Mitra yang tergabung dalam PT TPI mendapatkan perlakuan-perlakuan tertentu yang dapat menunjukkan adanya indikasi perlakuan diskriminasi terhadap mitra. Sebagaimana diskriminasi merupakan bagian dari penguasaan pasar, yakni tertera pada Pasal 19 huruf d UU 5/1999 serta merujuk pada Peraturan KPPU 3/2011 bahwa praktek diskriminasi terhadap pelaku usaha dapat berupa penentuan perlakuan dengan cara yang berbeda mengenai persyaratan pemasokan atau persyaratan pada pembelian barang dan/atau jasa dengan tanpa adanya justifikasi.

Praktek diskriminasi juga diartikan sebagai perilaku yang tidak memiliki justifikasi secara sosial, ekonomi, teknis, ataupun pertimbangan efisiensi lainnya, karena apabila dalam melakukan praktek diskriminasi tersebut terdapat penunjukkan langsung, menolak melakukan hubungan usaha dengan pihak tertentu, dan menetapkan syarat tertentu kepada suatu pelaku usaha yang tidak memiliki alasan untuk kepentingan legal, sosial, ekonomi, dan alasan teknis lainnya yang dapat diterima maka termasuk dalam pelanggaran Pasal 19 huruf d UU 5/1999 terkait praktek diskriminasi. Praktek diskriminasi juga harus mempunyai dampak yang menyebabkan persaingan usaha yang tidak sehat, bisa dalam posisi horizontal pada pasar pelaku praktek diskriminasi dan/atau posisi vertikal pada pasar korban dari praktek diskriminasi. ${ }^{77}$

Indikasi adanya praktek diskriminasi yang terjadi pada mitra adalah berupa adanya PT Grab dan PT TPI yang melakukan perjanjian secara Bersama-sama

\footnotetext{
${ }^{76}$ Putusan Putusan Komisi Pengawas Persaingan Usaha Nomor 13/KPPU-I/2019.

${ }^{77}$ Peraturan Komisi Pengawas Persaingan Usaha Nomor 3 Tahun 2011 Tentang Pedoman Pasal 19 Huruf D (Praktek Diskriminasi) Undang-Undang Nomor 5 Tahun 1999 Tentang Larangan Praktek Monopoli dan Persaingan Usaha Tidak Sehat.[16].
} 
untuk menyingkirkan pelaku usaha pesaing dari PT TPI yang mengakibatkan adanya hambatan pada persaingan dalam penyediaan jasa angkutan sewa khusus. PT Grab melakukan diskriminasi kepada mitra yang tidak tergabung dengan PT TPI dengan cara pemberian perlakuan istimewa kepada PT TPI beserta mitra yang tergabung. Bentuk perlakuan istimewa yang diberikan oleh PT Grab kepada PT TPI beserta mitra yang tergabung adalah pemberian skema perhitungan yang berbeda antara mitra yang tergabung dengan PT TPI dengan mitra yang tidak tergabung atau individu, adanya pembedaan dalam pemberian sistem insentif antara mitra yang tergabung dengan PT TPI dan mitra yang tidak tergabung atau individu, dan pemberlakuan pembedaan terhadap sistem suspend antara mitra dari PT TPI dengan mitra non PT TPI yang pada mitra dari PT TPI diberlakukan sistem open suspend kepada mitra yang terkena sanksi suspend. ${ }^{78}$

\section{Kesimpulan}

Karakteristik dari perilaku penguasaan pasar pada perusahaan transportasi online adalah struktur pasarnya oligopoli yang berbentuk duopoli, karena saat ini hanya ada dua pelaku usaha yang menjalankan bidang transportasi online tersebut. Sehubungan dengan karakteristiknya yang yang merupakan struktur pasar duopoli, perusahaan tersebut yakni, PT Grab dan PT Gojek merupakan perusahaan besar, karena salah satu syarat untuk memasuki struktur pasar duopoli adalah perusahaan besar. Statusnya sebagai perusahaan besar membuat PT Grab dan PT Gojek berada pada posisi dominan yang dapat menghalangi pelaku usaha yang lainnya apabila melakukan penguasaan pasar.

\section{Daftar Bacaan}

\section{Buku}

Budi L. Kagramanto, Mengenal Hukum Persaingan Usaha (Laros 2012).

Adiwarman A. Karim, Ekonomi Mikro Islami (Raja Grafindo Persada 2007).

\footnotetext{
${ }^{78}$ Putusan Komisi Pengawas Persaingan Usaha NOMOR 13/KPPU-I/2019.Loc.Cit.
} 
Andi Fahmi Lubis, Hukum Persaingan Usaha Buku Teks (KPPU 2017).

Peter Mahmud Marzuki, Penelitian Hukum (Prenada Media 2005).

Maya Panorama, Struktur Pasar, Analisis Menggunakan Kurva (Idea Press 2016).

\section{Jurnal}

Amalia, Lia, 'Perspektif Hukum Persaingan Usaha Terhadap Duopoli Pelaku Usaha Transportasi Online di Indonesia' (2020) 3 Widya Yuridika Jurnal Hukum.

Gawas, Vijay M, 'Doctrinal Legal Research Method A Guiding Principle In Reforming The Law And Legal System Towards The Research Development', (2017) 3 International Journal of Law.

Wahyusetyawati, Endang, 'Dilema Pengaturan Transportasi Online' (2017) RechtsVinding.

\section{Laman}

Ahmad Zaenudin, 'Kala Grab dan Gojek Goyah Akibat Corona' (Tirto.id, 2020) $<$ https://tirto.id/kala-grab-dan-gojek-goyah-akibat-corona-fKxg $>$ diakses pada 21 Juni 2021.

Kevin Anthony, 'Mengenal Penguasa Transportasi Online di Berbagai Negara' (CNBC Indonesia, 2018) <https://www.cnbcindonesia.com/ news/20180217144830-4-4629/mengenal-penguasa-transportasi-online-diberbagai-negara $>$ accessed 26 Januari 2021.

Roy Franedya, 'Siapa penguasa sejati pasar ojol RI, Grab atau Gojek?', CNBC Indonesia, 2019) <https://www.cnbcindonesia.com/tech/2019122706525437-125903/siapa-penguasa-sejati-pasar-ojol-ri-grab-atau-gojek/2> accessed 13 Juni 2021.

Aulia Masna, 'Layanan Uber Resmi Hadir di Jakarta Hari Ini', (Daily Social 2014) $<$ https://dailysocial.id/post/layanan-uber-resmi-hadir-di-jakarta-hari-ini>.

R1, 'Daftar Penyedia Jasa Transportasi Online di Indonesia' (Reaktor.co.id, 2014) $<$ https://reaktor.co.id/daftar-penyedia-jasa-transportasi-online-diindonesia/> accessed 28 September 2020.

Sidharta, 'catatan seputar hukum persaingan usaha' (Business Law Binus, 2013) $<$ https://business-law.binus.ac.id/2013/01/20/catatan-seputar-hukumpersaingan-usaha/> accssed 28 September 2020. 


\section{Peraturan Perundang-undangan}

Undang-undang Nomor 5 Tahun 1999 tentang Larangan Praktek Monopoli dan Persaingan Usaha Tidak Sehat (Lembaran Negara Republik Indonesia Tahun 1999 Nomor 3, Tambahan Lembaran Negara Republik Indonesia Nomor 3817).

Komisi Pengawas Persaingan Usaha, DRAFT Pedoman Pelaksanaan Ketentuan Pasal 19 UU 5/1999.

Peraturan Komisi Pengawas Persaingan Usaha Nomor 3 Tahun 2009 Tentang Pedoman Penerapan Pasal 1 angka 10 tentang Pasar Bersangkutan Berdasarkan Undang-Undang Nomor 5 Tahun 1999 Tentang Larangan Praktek Monopoli dan Persaingan Usaha Tidak Sehat.

Peraturan KPPU Nomor 6 Tahun 2010 tentang Pedoman pasal 25 UU 5/1999.

Peraturan Komisi Pengawas Persaingan Usaha Nomor 3 Tahun 2011 Tentang Pedoman Pasal 19 Huruf D (Praktek Diskriminasi) Undang-Undang Nomor 5 Tahun 1999 Tentang Larangan Praktek Monopoli dan Persaingan Usaha Tidak Sehat.

Putusan Komisi Pengawas Persaingan Usaha Nomor 13/KPPU-I/2019. 